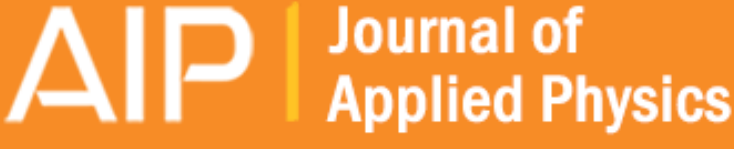

\section{Cell adhesion and growth on surfaces modified by plasma and ion implantation}

W. W. R. Araujo, F. S. Teixeira, G. N. da Silva, D. M. F. Salvadori, and M. C. Salvadori

Citation: Journal of Applied Physics 115, 154701 (2014); doi: 10.1063/1.4871541

View online: http://dx.doi.org/10.1063/1.4871541

View Table of Contents: http://scitation.aip.org/content/aip/journal/jap/115/15?ver=pdfcov

Published by the AIP Publishing

\section{Articles you may be interested in}

Epithelial cell morphology and adhesion on diamond films deposited and chemically modified by plasma processes

Biointerphases 9, 031012 (2014); 10.1116/1.4890471

Enhancement of hemocompatibility on titanium implant with titanium-doped diamond-like carbon film evaluated by cellular reactions using bone marrow cell cultures in vitro J. Vac. Sci. Technol. B 27, 1559 (2009); 10.1116/1.3077271

Development of a regeneration-type neural interface: A microtube guide for axon growth of neuronal cells fabricated using focused-ion-beam chemical vapor deposition J. Vac. Sci. Technol. B 24, 2538 (2006); 10.1116/1.2359730

Improved adhesion of amorphous carbon thin films on glass by plasma treatment J. Vac. Sci. Technol. A 22, 1297 (2004); 10.1116/1.1735867

Cell adhesion and spreading on polymer surfaces micropatterned by ion beams J. Vac. Sci. Technol. A 21, 1145 (2003); 10.1116/1.1575217

\section{AIP $\mid$ chaos CALL FOR APPLICANTS Seeking new Editor-in-Chief}




\title{
Cell adhesion and growth on surfaces modified by plasma and ion implantation
}

\author{
W. W. R. Araujo, ${ }^{1, a)}$ F. S. Teixeira, ${ }^{1}$ G. N. da Silva, ${ }^{2}$ D. M. F. Salvadori, ${ }^{3}$ and M. C. Salvadori ${ }^{1}$ \\ ${ }_{1}^{1}$ Institute of Physics, University of São Paulo, C.P. 66318, CEP 05315-970 São Paulo, Brazil \\ ${ }^{2}$ Clinical Analyses Department, Pharmacy School, Federal University of Ouro Preto, UFOP, Ouro Preto, \\ Minas Gerais, Brazil \\ ${ }^{3}$ Department Pathology, Faculty of Medicine, São Paulo State University, UNESP, São Paulo, Brazil
}

(Received 21 February 2014; accepted 4 April 2014; published online 15 April 2014)

\begin{abstract}
In this study, we show and discuss the results of the interaction of living CHO (Chinese Hamster Ovary) cells, in terms of adhesion and growth on glass, SU-8 (epoxi photoresist), PDMS (polydimethylsiloxane), and DLC (hydrogen free diamond-like carbon) surfaces. Glass, SU-8, and DLC but not PDMS showed to be good surfaces for cell growth. DLC surfaces were treated by oxygen plasma (DLC-O) and sulfur hexafluoride plasma (DLC-F). After $24 \mathrm{~h}$ of cell culture, the number of cells on DLC-O was higher than on DLC-F surface. SU-8 with silver implanted, creating nanoparticles $12 \mathrm{~nm}$ below the surface, increased significantly the number of cells per unit area. (C) 2014 AIP Publishing LLC. [http://dx.doi.org/10.1063/1.4871541]
\end{abstract}

\section{INTRODUCTION}

Surface modifications from organic ${ }^{1}$ to inorganic materials, ${ }^{2}$ have been widely used for cell growth, ${ }^{3-9}$ for a wide variety of applications, ranging from $\operatorname{cosmetics}^{10}$ to microelectronics industry. ${ }^{11}$ In this context, chemical treatments, including plasma surface modification, are commonly used, with considerable changes of surface properties, which influence the adhesion and proliferation of mammalian cells in a strong way. ${ }^{12}$ In the absence of cell surface ligands, the free surface energy is the main property correlated with cell adhesion. It is known that high surface energy promotes better cell adhesion and rapid cell spreading on the substrate, whereas low energy surfaces do not favor this type of behavior. $^{12}$

We evaluated four different pristine surfaces for cell adhesion and growth, namely, glass, SU-8 (epoxi photoresist), PDMS (polydimethylsiloxane), and DLC (hydrogen free diamond-like carbon). We also performed surface modification on DLC, using plasma treatment to form oxygen and fluorine terminations, and on SU-8, using silver ion implantation. This two modified surfaces were also evaluated concerning cell culture.

The choice of the materials was based on their properties and applications. SU-8 is an epoxi-based photo and electron beam resist used in a variety of applications, mainly using microfabrication techniques, such as microfluidics, superhydrophobicity, ${ }^{13-15}$ and bio-MEMS. ${ }^{16}$ Silver nanoparticles are known for their antibacterial properties. ${ }^{17}$ As it is known that implantation of metal into polymer using ion implantation forms nanoparticles inside the polymer, ${ }^{18-26}$ we evaluated the cell growth on buried silver nanoparticles into SU-8 formed by ion implantation. PDMS is a widely used polymeric material with several interesting characteristics, which include high flexibility, optical transparency,

\footnotetext{
a) Author to whom correspondence should be addressed. Electronic mail: wwlysses@if.usp.br. Tel.: +55 113091 6625. Fax: +55 1130916749.
}

biocompatibility, and ease to fabricate. ${ }^{27,28}$ Diamond-like carbon is an amorphous carbon material with high content of $\mathrm{sp}^{3}$ bonds, providing properties similar to diamond films, being also a biocompatible material.

The main objective of this study was to investigate the interaction of living cells, in terms of adhesion and growth, with these technologically interesting material surfaces.

\section{EXPERIMENTAL}

\section{A. Cell culture}

Chinese Hamster Ovary cells (CHO) in a freezing solution $(10 \%$ dimethyl sulfoxide (DMSO)) were stored in liquid nitrogen $\left(-195^{\circ} \mathrm{C}\right)$ in aliquots of $1 \times 10^{6}$ cells $/ \mathrm{ml}$ until be cultured. Then, cells were thawed and cultured in monolayers into culture flasks of $25 \mathrm{~cm}^{2}$ (Corning) in HAM- F10 medium (Invitrogen) supplemented with $10 \%$ fetal bovine serum (Cultilab) and antibiotics (streptomycin 1\% and penicillin $1 \%$ ). Cell cultures were incubated at $37^{\circ} \mathrm{C}$ and $5 \%$ $\mathrm{CO}_{2}$ until reach approximately $90 \%$ confluence. For subcultures, medium was removed and $5 \mathrm{ml}$ of Hanks $1 \mathrm{X}$ solution

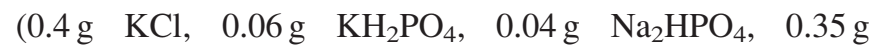
$\mathrm{NaHCO}_{3}, 1 \mathrm{~g}$ glucose, $8 \mathrm{~g} \mathrm{NaCl}, \mathrm{H}_{2} \mathrm{O}$ q.s.p. $1000 \mathrm{ml}$ ) were added for $2 \mathrm{~min}$. Afterwards, the Hanks solution was removed and $2 \mathrm{ml}$ of trypsin $0.25 \% /$ EDTA $1 \mathrm{X}$ (Invitrogen) were added for $5 \mathrm{~min}$, until cell detached. Subcultures were performed at 1:2 ratio, every $24 \mathrm{~h}$, in culture flasks of $25 \mathrm{~cm}^{2}$.

For evaluating cell growth and cell adhesion, each substrate was placed into a dish and then $1.2 \times 10^{5}$ exponentially growing cells were seeded (cultures in triplicate) and incubated for 24 h. $^{29,30}$ For cell adhesion, the criterion used was cells morphology. It is known that cells with spherical geometry present low adhesion to the substrate ${ }^{31}$ and high occurrence of this geometry means that the substrate is not favorable for cell growth. Thus, we define the form factor $F_{f}$ given by equation: ${ }^{31}$ 
TABLE I. Average form factor $\left(F_{f}\right)$, calculated by measuring 30 cells for each sample, and SFE for the selected substrates.

\begin{tabular}{lcc}
\hline \hline Sample & $F_{f}$ & SFE $(\mathrm{mN} / \mathrm{m})$ \\
\hline Glass & $0.50 \pm 0.03$ & $54 \pm 3$ \\
SU-8 & $0.52 \pm 0.03$ & $35 \pm 1$ \\
DLC & $0.54 \pm 0.03$ & $27 \pm 1$ \\
PDMS & $0.99 \pm 0.01$ & $9 \pm 1$ \\
\hline \hline
\end{tabular}

$$
F_{f}=4 \pi \frac{\text { area }}{{\text { (perimeter })^{2}}}
$$

where the area and perimeter of cells can be measured in an image of optical microscopy using software such as Image Pro from Media Cybernetics. The form factor $F_{f}$ can range from one (for a perfect circle) to almost zero (approximating a straight line, where the area would be almost zero). Thus, for elongated cells, $F_{f}$ will be low, while for the circular cells, representing low adhesion, $F_{f}$ will approach unity. In this way, we can numerically evaluate the cells adhesion to the substrate and the consequent suitability of the substrates for cell growth.

Initially, cell cultures were performed on substrates without pretreatment, i.e., without surface treatment. The substrates used were glass (cover slips from Glasstécnica), SU-8 (2005 from Micho Chem, resin used for electron beam lithography_electron resist), PDMS (from Dow Corning), and DLC on silicon, deposited by Metal Plasma Immersion Ion Implantation and Deposition (MePIIID). ${ }^{32}$ The evaluation of these cultures was performed calculating the cells form factors $\left(F_{f}\right)$.

Cell growth was proceeded on the modified surfaces and the number of live cells per unit area was performed for each substrate by optical microscopy. CHO cell viability after 24 $\mathrm{h}$ cell culture was performed using trypan blue exclusion methodology. Briefly, a freshly prepared solution of $500 \mu \mathrm{l}$ trypan blue $(0.05 \%)$ in distilled water was mixed to the same volume of fresh medium of culture. About 20-30 $\mu \mathrm{l}$ of this solution was placed on each substrate fully covering the surfaces that still contained attached cells. After $3 \mathrm{~min}$, optical microscopy images were acquired in five different regions of the surface. Dead cells were blue-stained. ${ }^{30}$

\section{B. Surface modification}

The materials used for surface modification were SU-8 and DLC. Silver ion implantation was performed in SU-8 substrates with dose of $1.2 \times 10^{16} \mathrm{~cm}^{-2}$ and energy of $8 \mathrm{keV}$. The implanter used has been described previously. ${ }^{33-35}$ Ion depth distribution inside SU-8 was simulated using the software Tridyn. ${ }^{36,37}$ The DLC samples were treated with oxygen plasma and with sulfur hexafluoride $\left(\mathrm{SF}_{6}\right)$ plasma, in separate samples, generating surfaces with oxygen terminations and fluorine terminations, respectively. ${ }^{38,39}$ The facility for plasma treatment has been described previously. ${ }^{40}$

\section{Contact angle and atomic force microscopy (AFM) imaging}

Contact angle was measured in a Goniometer KSV CAM 200 and the surface free energy (SFE) was evaluated using CAM SFE software with the method OWRK/Extended Fowkes. ${ }^{41}$ As liquid probes, we have used deionized water (18.2 M $\Omega$ cm, Millipore) and ethylene glycol (99.5\%, Merck).

AFM was used for imaging the SU-8 surface before and after the ion implantation. The microscope used was a NanoScope IIIA, from Bruker, in the intermittent contact mode. The tip radius used for the AFM image acquisition was $15 \mathrm{~nm}$ (nominal) and the cantilever resonant frequency was about $300 \mathrm{kHz}$.

\section{RESULTS AND DISCUSSION}

The form factors $\left(F_{f}\right)$ were calculated as an average value from measurements of 30 cells per image in 5 different regions for each sample. The results are listed in Table I, which shows that the samples of glass, SU-8, and DLC presented low values for the form factor, demonstrating a good cell spreading on these surfaces and consequent suitability of these substrates for cell growth. For the PDMS cells, the form factor obtained was the unit, attesting low cell spreading and consequent poor adhesion, indicating that PDMS was inadequate for cell growth. Considering these results, SU-8 and DLC were selected for surface modification.

The SFE was measured for all substrates and the results are also presented in Table I. The SFE obtained for PDMS is compatible with the form factor result, since low SFE promotes worst cell adhesion, ${ }^{12}$ generating cells with higher form factor. The SFE of the DLC and SU-8 have intermediate values compared with PDMS and glass, however, DLC and SU-8 present low form factor, suggesting good cell adhesion. Interestingly, despite of the significant difference between SFE of SU-8, DLC, and glass, the difference between their form factors were not so significant.

The results for DLC, DLC-O (treated by oxygen plasma), and DLC-F (treated with $\mathrm{SF}_{6}$ plasma) are shown in Figure 1, where the number of live cells per unit area is given for those three substrates, for three independent
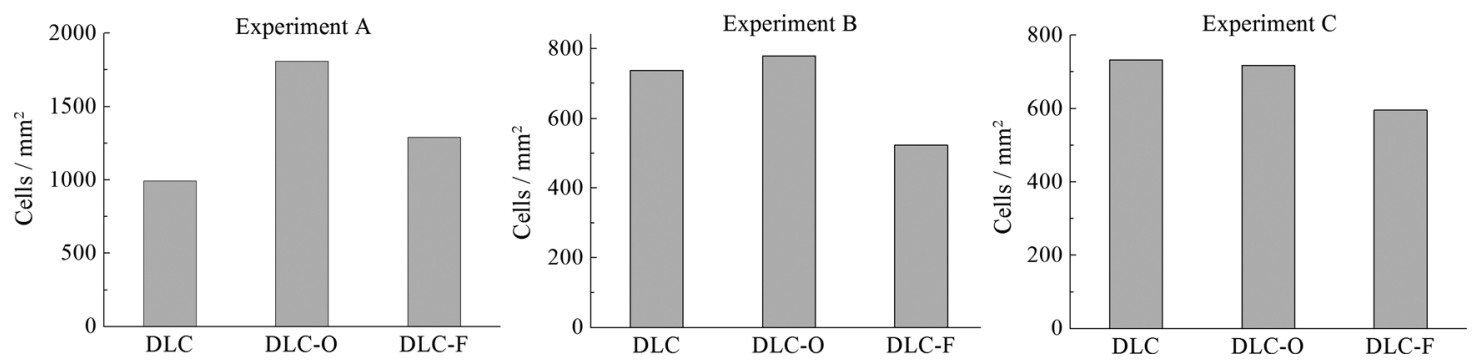

FIG. 1. Number of live cells per unit area for three substrates: DLC-O, DLC-F, and DLC without plasma treatment, for three independent experiments. 


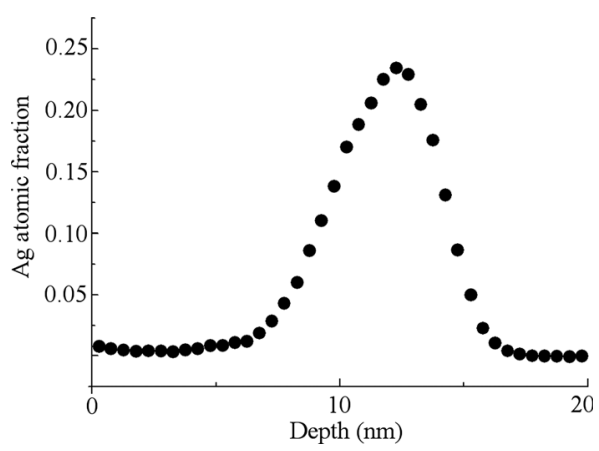

FIG. 2. Depth profile of Ag implanted in SU-8 for ion energy of $8 \mathrm{keV}$ and dose of $1.2 \times 10^{16} \mathrm{~cm}^{-2}$, as calculated by the TRIDYN simulation code. The maximum concentration of silver is located at approximately $12 \mathrm{~nm}$ below the surface.

experiments. The results, for all experiments, showed that the number of cells on the DLC-O was higher than on DLC-F. For better understanding this result, the wettability of the DLC-O and the DLC-F were evaluated by contact angle measurements. For the DLC-O, the contact angle obtained was $(63 \pm 2)^{\circ}(\mathrm{SFE}=39 \pm 1 \mathrm{mN} / \mathrm{m})$ and, for the DLC-F, was $(90 \pm 1)^{\circ}(\mathrm{SFE}=27 \pm 2 \mathrm{mN} / \mathrm{m})$, which is compatible with the literature results. ${ }^{42-44}$ These results agree with those previously reported by Duailibi et al. ${ }^{45}$ showing that hydrophilic surfaces benefit cell growth. Concerning to the DLC without plasma treatment, cell growth presented different behaviors for each of the three independent experiments. An explanation for that could be the possible randomness of chemical species present on the DLC surface without treatment, leading to non reproducible results.

Ion implantation was performed in SU-8 using silver (Ag) dose of $1.2 \times 10^{16} \mathrm{~cm}^{-2}$ (confirmed by Rutherford Backscattering Spectrometry-RBS) with energy of $8 \mathrm{keV}$. Figure 2 presents TRIDYN simulation, where the depth profile of Ag implanted in SU-8 is plotted. The maximum concentration of silver is located at approximately $12 \mathrm{~nm}$ below the surface, where the nanoparticles are formed. ${ }^{46}$
The result from cell culture in SU-8 with (SU-8/Ag) and without (SU-8) silver implantation is shown in Figure 3. The number of live and dead cells per unit area is given for both substrates, from three independent experiments. In all experiments, the number of cells on SU-8/Ag surface was higher than on original SU-8. Similarly, higher amount of dead cells was also detected on the SU-8/Ag surface. Nevertheless, considering that the number of dead cells was less than $1 \%$ of live cells per unit area, it is possible to conclude that the SU-8/Ag surface had better performance for cell growth.

The surface free energy of SU-8 was determined from contact angle measurements for the SU-8 $(35 \pm 1 \mathrm{mN} / \mathrm{m})$ and for the SU-8/Ag $(30 \pm 1 \mathrm{mN} / \mathrm{m})$. The difference between these values is too low for justifying the different cells behavior on these surfaces. Figure 4 presents AFM images of SU-8 surface with and without silver implantation. It is possible to observe that the implanted surface is nanostructured, but it is known ${ }^{47}$ that nano patterned surfaces can interfere with cell growth just when the structures have aspect ratio near unit, that is not this case, where the lateral size of the structures were in average $40 \mathrm{~nm}$ and the heights $5 \mathrm{~nm}$, giving an aspect ratio of 0.13 . Concerning to the surface area, the SU-8/Ag has $6.7 \%$ higher area than the original SU-8, which is compatible with the low aspect ratio of the structures. In this way, these nanostructures do not justify also the different cells behavior on the SU-8 and SU-8/Ag surfaces. A possible reason for the better performance for the cell growth on SU-8/Ag is the possibility of the cells access the silver nanoparticles $12 \mathrm{~nm}$ below the surface, generating benefits for the cells culture.

\section{SUMMARY AND CONCLUSION}

CHO cells were cultured on glass, SU-8, DLC, and PDMS surfaces and the criterion of form factor analysis was used for evaluating the suitability of the substrates for this purpose. Glass, SU-8, and DLC presented low values for the
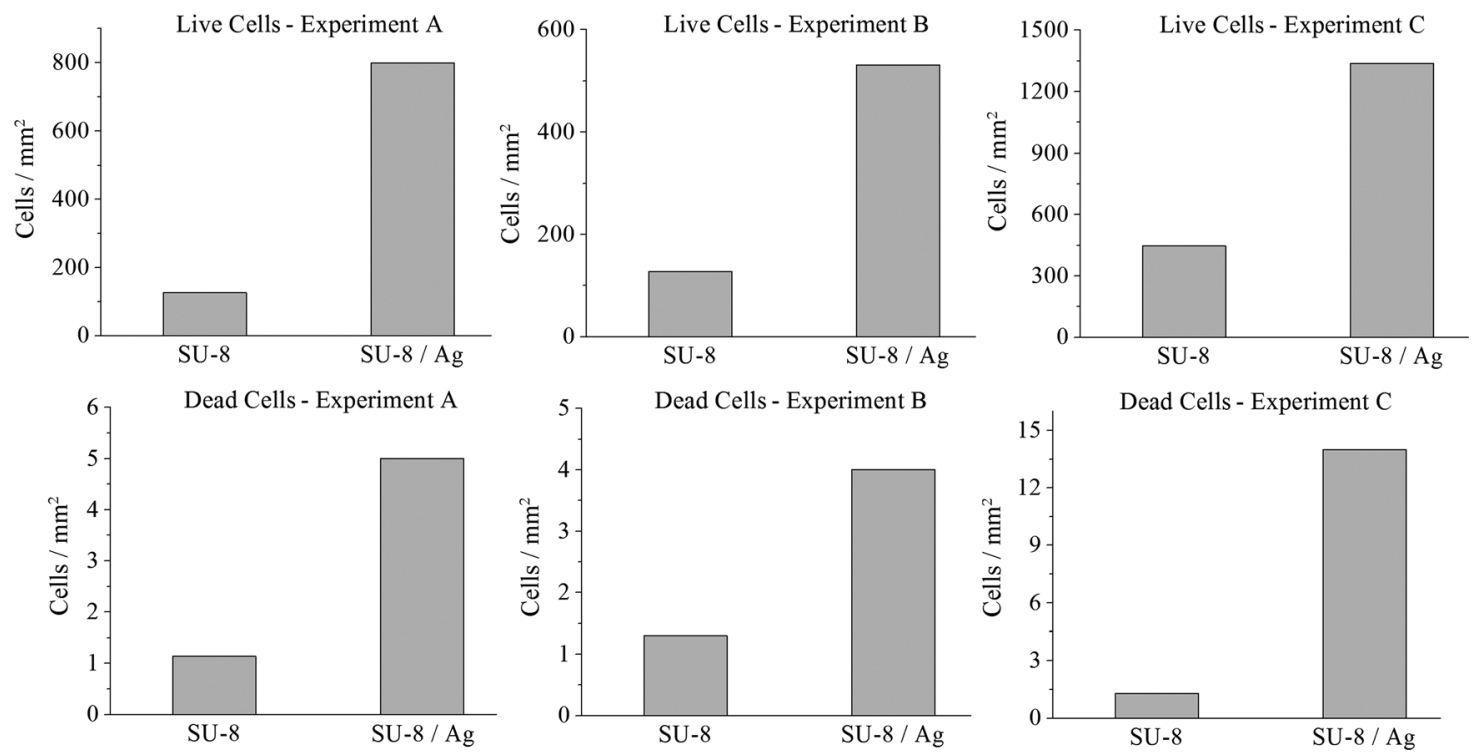

FIG. 3. Upper histograms: number of live cells per unit area for substrates of SU-8 with and without silver implantation, for three independent experiments. Lower histograms: number of dead cells per unit area for substrates of SU-8 with and without silver implantation, for three independent experiments. 

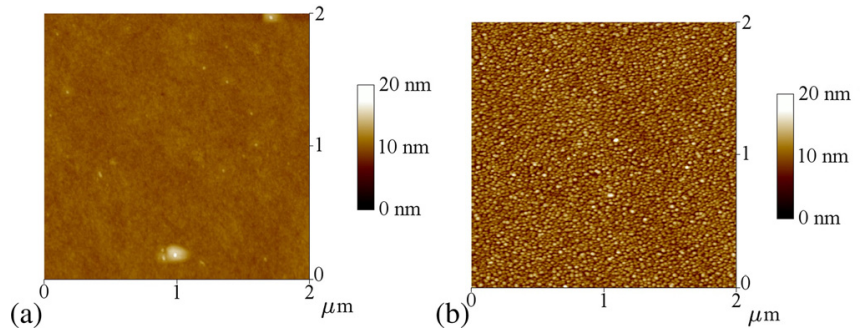

FIG. 4. AFM images of (a) original SU-8 and (b) SU-8 modified by Ag ion implantation.

form factor, demonstrating these materials are good for cell growth. For the PDMS surfaces, the form factor was the unit, indicating that PDMS is inadequate for cell growth.

DLC surfaces were treated by oxygen plasma (DLC-O) and sulfur hexafluoride plasma (DLC-F). CHO cells were cultured on DLC-O, DLC-F, and DLC without plasma treatment, and $24 \mathrm{~h}$ later, the number of cells on the DLC-O was higher than on DLC-F surface, what can be justified by the hydrophilicity of the DLC-O (contact angle of DLC-O was $(63 \pm 2)^{\circ}$ and of the DLC-F was $\left.(90 \pm 1)^{\circ}\right)$. The DLC without plasma treatment presented different behaviors on the cell growth for each of three independent experiments, possible because of the randomness of chemical species present on the DLC surface without treatment, leading to non reproducible results.

SU-8 with silver implanted, creating nanoparticles $12 \mathrm{~nm}$ below the surface, brought exciting new results in terms of increasing the number of cells for three independent experiments. The surface free energy of SU-8 with and without silver implantation is very similar, which does not justify the different cells behavior on these surfaces. AFM image of SU-8 with silver implantation shows nanostructures with aspect ratio of 0.13 that is too low for justifying the different cells behavior on the surfaces. A possible reason for the better performance for the cell growth on SU-8/Ag is the possibility of the cells access the silver nanoparticles $12 \mathrm{~nm}$ below the surface, generating benefits for the cells culture.

\section{ACKNOWLEDGMENTS}

This study was supported by the Fundação de Amparo a Pesquisa do Estado de São Paulo (FAPESP) and the Conselho Nacional de Desenvolvimento Científico e Tecnológico (CNPq), Brazil.

${ }^{1}$ S.-W. Lee, K. E. Tettey, I. L. Kim, J. A. Burdick, and D. Lee, Macromolecules 45, 6120 (2012).

${ }^{2}$ A. V. Singh, V. Vyas, R. Patil, V. Sharma, P. E. Scopelliti et al., PLoS One 6, e25029 (2011).

${ }^{3}$ A. V. Vashi, J. A. M. Ramshaw, V. Glattauer, C. M. Elvin, R. E. Lyons, and J. A. Werkmeister, Biofabrication 5, 035005 (2013).

${ }^{4}$ B. N. Lourenço, G. Marchioli, W. Song, R. L. Reis, C. A. van Blitterswijk, M. Karperien, A. van Apeldoorn, and J. F. Mano, Biointerphases 7, 46 (2012).

${ }^{5}$ G. Y. Park, S. J. Park, M. Y. Choi, I. G. Koo, J. H. Byun, J. W. Hong, J. Y. Sim, G. J. Collins, and J. K. Lee, Plasma Sources Sci. Technol. 21, 043001 (2012).

${ }^{6}$ A. Cifuentes and S. Borrós, Langmuir 29, 6645 (2013).

${ }^{7}$ M. G. Bellino, S. Golbert, M. C. De Marzi, G. J. A. A. Soler-Illia, and M. F. Desimone, Biomater. Sci. 1, 186 (2013).
${ }^{8}$ M. Schernthaner, B. Reisinger, H. Wolinski, S. D. Kohlwein, A. TrantinaYates, M. Fahrner, C. Romanin, H. Itani, D. Stifter, G. Leitinger, K. Groschner, and J. Heitz, Acta Biomater. 8, 2953 (2012).

${ }^{9}$ A. Ruiz, C. E. Flanagan, and K. S. Masters, J. Biomed. Mater. Res. Part A 101, 2870 (2013).

${ }^{10}$ B. Bhushan, W. Tang, and S. Ge, J. Microsc. 240, 135 (2010).

${ }^{11}$ A. Doerr, Nat. Methods 10, 818 (2013).

${ }^{12}$ S. A. Mitchell, N. Emmison, and A. G. Shard, Surf. Interface Anal. 33, 742 (2002).

${ }^{13}$ M. C. Salvadori, M. R. S. Oliveira, R. Spirin, F. S. Teixeira, M. Cattani, and I. G. Brown, J. Appl. Phys. 114, 174911 (2013).

${ }^{14}$ M. C. Salvadori, M. Cattani, M. R. S. Oliveira, F. S. Teixeira, and I. G. Brown, Appl. Phys. Lett. 96, 074101 (2010).

${ }^{15}$ M. C. Salvadori, M. Cattani, M. R. S. Oliveira, F. S. Teixeira, and I. G. Brown, J. Appl. Phys. 108, 024908 (2010).

${ }^{16}$ G. Perry, F. Lapierre, Y. Coffinier, V. Thomy, R. Boukherroub, C. Lu, S. H. Tsang, B. K. Tay, and P. Coquet, in Proceedings of the IEEE 5th International Nanoelectronics Conference (INEC) (2013), p. 374.

${ }^{17}$ J. R. Morones-Ramirez, J. A. Winkler, C. S. Spina, and J. J. Collins, Sci. Transl. Med. 5, 190ra81 (2013).

${ }^{18}$ M. C. Salvadori, M. Cattani, F. S. Teixeira, and I. G. Brown, Appl. Phys. Lett. 93, 073102 (2008).

${ }^{19}$ F. S. Teixeira, M. C. Salvadori, M. Cattani, and I. G. Brown, J. Appl. Phys. 105, 064313 (2009).

${ }^{20}$ F. S. Teixeira, M. C. Salvadori, M. Cattani, S. M. Carneiro, and I. G. Brown, J. Vac. Sci. Technol. B 27, 2242 (2009).

${ }^{21}$ F. S. Teixeira, M. C. Salvadori, M. Cattani, and I. G. Brown, J. Vac. Sci. Technol. A 28, 818 (2010).

${ }^{22}$ F. S. Teixeira, M. C. Salvadori, M. Cattani, and I. G. Brown, J. Appl. Phys. 106, 056106 (2009).

${ }^{23}$ F. S. Teixeira, M. C. Salvadori, M. Cattani, and I. G. Brown, J. Appl. Phys. 108, 093505 (2010).

${ }^{24}$ F. S. Teixeira, M. C. Salvadori, M. Cattani, and I. G. Brown, J. Appl. Phys. 111, 104311 (2012).

${ }^{25}$ M. C. Salvadori, F. S. Teixeira, M. Cattani, and I. G. Brown, J. Appl. Phys. 110, 114905 (2011).

${ }^{26}$ J. Ferreira, F. S. Teixeira, A. R. Zanatta, M. C. Salvadori, R. Gordon, and O. N. Oliveira Jr., Phys. Chem. Chem. Phys. 14, 2050 (2012).

${ }^{27}$ J. Zhang, Y. Chen, and M. A. Brook, Langmuir 29, 12432 (2013).

${ }^{28}$ K. Mogi and T. Fujii, Lab Chip 13, 1044 (2013).

${ }^{29}$ T. Sordel et al., Biomaterials 28, 1572 (2007).

${ }^{30}$ D. A. Ribeiro, M. E. A. Marques, and D. M. F. Salvadori, J. Mater. Sci.: Mater. Med. 17, 495 (2006).

${ }^{31}$ A. K. Shah, R. K. Sinha, N. J. Hickok, and R. S. Tuan, Bone 24, 499 (1999).

${ }^{32}$ M. C. Salvadori, F. S. Teixeira, W. W. R. Araujo, L. G. Sgubin, and I. G. Brown, Diamond Relat. Mater. 25, 8 (2012).

${ }^{33}$ M. C. Salvadori, F. S. Teixeira, L. G. Sgubin, W. W. R. Araujo, R. E. Spirin, M. Cattani, E. M. Oks, and I. G. Brown, Rev. Sci. Instrum. 85, 02B502 (2014).

${ }^{34}$ M. C. Salvadori, F. S. Teixeira, L. G. Sgubin, W. W. R. Araujo, R. E. Spirin, E. M. Oks, and I. G. Brown, Rev. Sci. Instrum. 84, 023506 (2013).

${ }^{35}$ M. C. Salvadori, F. S. Teixeira, L. G. Sgubin, W. W. R. Araujo, R. E. Spirin, E. M. Oks, K. M. Yu, and I. G. Brown, Appl. Phys. Lett. 101, 224104 (2012).

${ }^{36}$ W. Möller and W. Eckstein, Nucl. Instrum. Methods Phys. Res., Sect. B 2, 814 (1984).

${ }^{37}$ W. Möller, W. Eckstein, and J. P. Biersack, Comput. Phys. Commun. 51, 355 (1988).

${ }^{38}$ M. C. Salvadori, W. W. R. Araújo, F. S. Teixeira, M. Cattani, A. Pasquarelli, E. M. Oks, and I. G. Brown, Diamond Relat. Mater. 19, 324 (2010).

${ }^{39}$ W. W. R. Araujo, M. C. Salvadori, F. S. Teixeira, M. Cattani, and I. G. Brown, Microsc. Res. Tech. 75, 977 (2012).

${ }^{40}$ A. Vizir, E. M. Oks, M. C. Salvadori, F. S. Teixeira, and I. G. Brown, Rev. Sci. Instrum. 78, 086103 (2007).

${ }^{41}$ D. K. Owens and R. C. Wendt, J. Appl. Polym. Sci. 13, 1741 (1969).

${ }^{42}$ S. C. H. Kwok et al., Diamond Relat. Mater. 14, 78 (2005).

${ }^{43}$ M. Shinohara et al., IEEE Trans. Plasma Sci. 40, 2756 (2012).

${ }^{44}$ M. Schvartzman and S. J. Wind, Nanotechnology 20, 145306 (2009).

${ }^{45}$ S. E. Duailibi, M. T. Duailibi, L. M. Ferreira, K. I. L. C. Salmazi, M. C. Salvadori, F. S. Teixeira, A. Pasquarelli, J. P. Vacanti, and P. C. Yelick, Tissue Eng. 19, 2537 (2013).

${ }^{46}$ A. L. Stepanov, D. E. Hole, and P. D. Townsend, J. Non-Cryst. Solids 260, 65 (1999).

${ }^{47}$ S. H. Chung, S. J. Son, and J. Min, Nanotechnology 21, 125104 (2010). 